\title{
Communication
}

\section{Trends in Outbreaks of Defoliating Insects Highlight Growing Threats for Central European Forests, and Implications for Eastern Baltic Region}

\author{
Ingars Siliṇš ${ }^{1}$, Annija Kārkliṇa ${ }^{1} \mathbb{D}$, Olga Miezīte ${ }^{2}$ and Āris Jansons ${ }^{1, *}$ \\ 1 Latvian State Forest Research Institute "Silava", 111 Rigas str., LV-2169 Salaspils, Latvia; \\ ingars.silins@silava.lv (I.S.); annija.karklina@silava.lv (A.K.) \\ 2 Forestry Faculty, Latvia University of Life Sciences and Technologies, Liela str. 2, LV-3001 Jelgava, Latvia; \\ olga.miezite@llu.lv \\ * Correspondence: aris.jansons@silava.lv; Tel.: +371-29109529
}

Citation: Silinšš, I.; Kārklina, A.; Miezīte, O.; Jansons, Ā. Trends in Outbreaks of Defoliating Insects Highlight Growing Threats for Central European Forests, and Implications for Eastern Baltic Region. Forests 2021, 12, 799. https:// doi.org/10.3390/f12060799

Academic Editor: Timothy A. Martin

Received: 20 May 2021

Accepted: 16 June 2021

Published: 17 June 2021

Publisher's Note: MDPI stays neutral with regard to jurisdictional claims in published maps and institutional affiliations.

Copyright: (c) 2021 by the authors. Licensee MDPI, Basel, Switzerland. This article is an open access article distributed under the terms and conditions of the Creative Commons Attribution (CC BY) license (https:// creativecommons.org/licenses/by/ $4.0 /)$.

\begin{abstract}
To identify general patterns in the effect of climate-driven changes in the outbreak frequency of forest defoliating species, we examined 60 years of records (1950-2010) of outbreaks of five defoliating species. Data on Lymantria dispar, Lymantria monacha, Bupalus piniarius, Panolis flammea, and Operophtera brumata from five Central European countries (Slovakia, Czech Republic, Austria, Hungary, and Germany), where the current climate is comparable with the projections of climate for the Eastern Baltic region by the end of the 21st century, were analyzed. Time series approach was applied to estimate the linkage between outbreaks and climate warming. Mean annual, summer, and winter deviations for the period of 1850 to 1900 were assessed as proxies of warming. To estimate the legacy effect, warming proxies were lagged by one year. Among those tested, warming proxies showed a linkage with outbreaks. Three significant outbreaks occurred in the analyzed period (at the beginning and end of the period). During the middle part of the analyzed period, the frequency and magnitude of outbreaks were low, implicating a higher insect outbreak risk with warming in Central Europe. In the latter part of the analyzed period, more frequent yet smaller outbreaks occurred, which supports the outbreak linkage with one-year lag, summer, and annual temperatures.
\end{abstract}

Keywords: defoliating insects; outbreaks; warming; temperature deviations

\section{Introduction}

Natural disturbances are key processes of forest ecosystem dynamics that change forest structure at the spatial and temporal scales [1]. Thus, disturbances such as storms, fires, and insect outbreaks are an inherent part of forest ecosystems [2]. The ongoing climate change shifts the frequency and/or severity of natural disturbances as well as the means and amplitude of meteorological parameters and thus has direct and indirect effects on insects and trees [3,4]. The changing climate, particularly temperature, has a direct effect on insects, which might facilitate their development and survival [5]. Therefore, global warming can promote insect outbreaks; however, the ongoing increase in optimum temperature might lead to the disruption of diapause requirements and spring development of insects. This might lead to a decrease in outbreak frequency and severity [6]. Additionally, an indirect effect of warming could influence the spatial distribution of host trees and their suitability to insects [6,7].

Contrasting effects of temperature on insect population size and geographical ranges have been reported [8]. Several studies show that the increasing temperature could force species distribution towards higher elevations and/or latitudes, leading to a loss of species, due to a small geographical range [8-10]. For many species, temperature changes might expand their geographical range [8], increasing development, reproduction, and survival rates [11,12]. Global warming might also have a negative impact on insects, as their thermal 
tolerance is to be exceeded, and extreme weather events could lead to a reduction in the population size [13].

The accelerating warming in temperate and boreal zones is expected to promote insect development and outbreaks that could amplify defoliation on trees [14,15]. Although reduced snow cover and earlier snowmelt might decrease winter survival, earlier and longer vegetation periods may favor species development due to earlier food supplies and longer growing seasons $[16,17]$. This appears particular for moths, for which the overwintering conditions are significantly improving $[14,16,17]$ due to increased temperature and less frequent cold spells [14,15]. For instance in Finland, the outbreak of Operophtera brumata in mountain birch forests has been reported [18].

It has been considered that warming might lead to the decoupling of phenological synchrony between both pests and parasitoids [19]. The differences between their heat limits can result in changed relative development rates that could affect their population biology [20]; therefore, their host-parasitoid synchronization could be disrupted [20]. Climatic events such as drought and storms can weaken trees, which renders them to be more susceptible to insect attacks [21]. However, the combination of drought periods and increasing temperature, which weakens trees, and population size of insects vs. parasitoids are the main drivers of outbreaks under the changing climate conditions [22]; however, their interactions are complex. In this regard, retrospection can provide an insight into the main factors affecting insect outbreaks, thus improving the accuracy of future projections. Therefore, the aim of this study was to assess trends in outbreaks of defoliators in Central European forests. We hypothesized that warming increases the frequency and magnitude of insect outbreaks.

\section{Materials and Methods}

\subsection{Data Selection}

The data on outbreak history in five Central European countries (Slovakia, Czech Republic, Austria, Hungary, and Germany) were acquired from FAO [23]. Additionally, a literature survey via European Forest Institute (https: / / www.efi.int / (accessed on 15 March 2019)), Global Invasive Species Database (http:/ / www.iucngisd.org/gisd/ (accessed on 11 April 2019)), Fauna European Database (https:/ / fauna-eu.org/ (accessed on 1 April 2019)), and Google Scholar (https:/ / scholar.google.com/ (accessed on 21 May 2020)) were obtained. From these databases, information on total defoliated area $\left(\mathrm{km}^{2}\right)$ by each species per year was acquired. The defoliating lepidopterans (moths)-Lymantria dispar, Lymantria monacha, Bupalus piniarius, Panolis flammea, and Operophtera brumata, which are widespread in Central and Northern Europe and have similar development cycles, cyclic population dynamics, and frequent outbreaks-were selected. The selected species pose a significant threat to economically important tree species, particularly increasing tree vulnerability and mortality. The climatic variables, including monthly mean temperature, were obtained from IPCC [24].

\subsection{Data Analysis}

The time series approach was used to analyze outbreak history and its linkage with warming. The autocorrelation coefficients for the selected outbreak data were estimated to evaluate autoregressiveness, hence the legacy effect of outbreaks. Subsequently, autocorrelation was removed when establishing standard outbreak chronology. Deviations in mean annual, winter, and summer temperatures from the mean values for the period of 1850-1900 were calculated as the proxies for warming in the investigated countries. To estimate the linkage between outbreaks and warming, linear regression was used. Additionally, the time series of warming proxies were lagged by one year to assess their legacies on the interannual variabilities of outbreaks. 


\section{Results and Discussion}

Cyclic outbreaks of forest defoliators in Central Europe were observed. In total, $1,100,000 \mathrm{~km}^{2}\left(4600 \mathrm{~km}^{2}\right.$ per year) of forests were defoliated by the selected species during the studied period. Six significant outbreaks occurred during the assessed period-in 1957, 1965, 1996, 2001, 2003, and 2009 (Figure 1A). The affected areas by defoliators reached $82,000 \mathrm{~km}^{2}$ in 1957 , increased to $140,000 \mathrm{~km}^{2}$ in 1965 , and ranged from 10,500 to $38,200 \mathrm{~km}^{2}$ from 1995 to 2010 (Figure 1A). The large-scale outbreaks became more frequent in the latter part of the analyzed periods. However, during the period from 1970 to 1990, no significant defoliation events were recorded (Figure 1A), which might be related to the gradual transition of stand compositions from pure to mixed in Central Europe [25], which can alter (moderate) defoliator behavior [26]. As the projection suggests, the climate conditions of the Eastern Baltic region are to become comparable to the current climate of Central Europe conditions by the end of the 21st century [24,27], and similar trends in defoliator behavior might be expected. This is also supported by the comparable composition of forests in Central Europe and the Eastern Baltic region [28]. Therefore, if the ongoing warming and forestry practices remain constant, the severity and frequency of outbreaks of defoliators in the Eastern Baltic region are expected to increase. The increase in outbreak frequency occurred only at the end of the twentieth century, suggesting a common trend in both climate and forest conditions [25]. However, after each cycle, the decreased probability of outbreaks was estimated after the peak in it (Figure 1B).
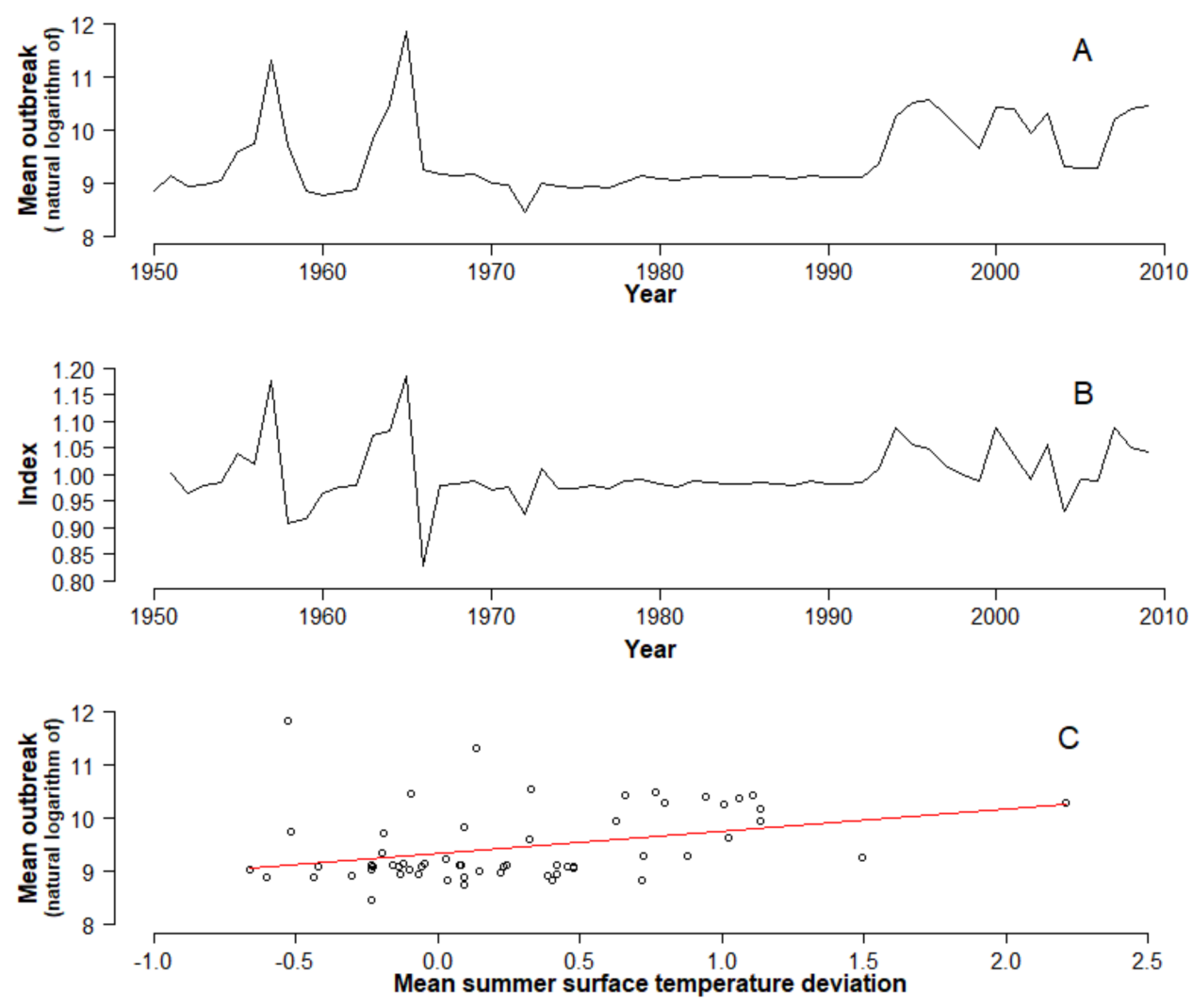

Figure 1. Area (A), interannual variability (B), and dependence of outbreak area on temperature deviation (C) during the period from 1950 to 2010 of the studied forest insect pests.

The interannual variabilities of outbreaks (their area) were affected by temperature deviations (Table 1$)$. The mean annual $(p=0.03)$, one-year-lagged summer $(p=0.02)$, and summer temperature $(p=0.007)$ had a significant effect on the mean outbreak area. For a better illustration, summer temperature deviations were used (Figure 1C). This shows that climate warming might have promoted insect outbreaks. However, the impact of 
drought periods on defoliating insects is ambiguous [25]. In several studies, insect survival, density, and performance decreased due to drought conditions [29,30], and their decline in performance was proportional to drought length and intensity [6,30-32]. Moreover, there is a linkage (feedback loop) between the population densities of defoliator caterpillars and great (Parus major) and blue tits (Parus caeruleus) [33]. Caterpillars of defoliators are preferred food sources of tits, and insect population density peaks (outbreaks) match with the hatching of chicks [33]. Therefore, predictions of the outbreak dynamic of defoliators have many uncertainties, mainly because of conflicting evidence [6]. Still, it is complicated to predict defoliator dynamics due to changing weather patterns, extreme climatic events, and different plant-insect-parasitoid interactions $[4,6]$.

Table 1. Regression analysis showing the effect of insect outbreaks and temperature deviations in Central Europe during the selected study period.

\begin{tabular}{ccc}
\hline Mean Temperature Deviations & $\mathbf{R}^{\mathbf{2}}$ & $p$-Value \\
\hline annual & 0.06 & 0.03 \\
winter & 0.01 & 0.20 \\
summer & 0.10 & 0.01 \\
one-year lagged & & 0.10 \\
annual & 0.03 & 0.90 \\
winter & -0.02 & 0.02 \\
\hline
\end{tabular}

\section{Conclusions}

A linkage between outbreak and temperature deviations was found, suggesting that increasing temperature facilitates the outbreak frequency in Central Europe. However, the increase in the proportion of mixed stands likely mitigated the outbreak activity, suggesting that similar management practices might be effective for the reduction in defoliator damage in the Eastern Baltic region. If the forestry practice remains the same (emphasis on pure stands), an increase in severity and frequency is expected.

Author Contributions: Conceptualization, I.S. and Ā.J.; methodology, I.S. and O.M.; formal analysis, I.S., A.K. and O.M.; data curation, I.S.; writing—original draft preparation, I.S. and A.K.; writingreview and editing, O.M. and Ā.J.; project administration, A..J. All authors have read and agreed to the published version of the manuscript.

Funding: The study was conducted as part of LVM research project "Effect of climate change on forestry and associated risks".

Data Availability Statement: Not applicable.

Acknowledgments: The authors declare that they have no known competing financial interests or personal relationships that could have appeared to influence the work reported in this paper.

Conflicts of Interest: The authors declare no conflict of interest.

\section{References}

1. Thom, D.; Seidl, R.; Steyrer, G.; Krehan, H.; Formayer, H. Slow and fast drivers of the natural disturbance regime in Central European forest ecosystems. For. Ecol. Manag. 2013, 307, 293-302. [CrossRef]

2. Van Lierop, P.; Lindquist, E.; Sathyapala, S.; Franceschini, G. Global forest area disturbance from fire, insect pests, diseases and severe weather events. For. Ecol. Manag. 2015, 352, 78-88. [CrossRef]

3. Ramsfield, T.D.; Bentz, B.J.; Faccoli, M.; Jactel, H.; Brockerhoff, E.G. Forest health in a changing world: Effects of globalization and climate change on forest insect and pathogen impacts. Forestry 2016, 89, 245-252. [CrossRef]

4. Senf, C.; Seidl, R. Mapping the forest disturbances regimes of Europe. Nat. Sustain. 2021, 4, 63-70. [CrossRef]

5. Bale, J.S.; Masters, G.J.; Hodkinson, I.D.; Awmack, C.; Bezemer, T.M.; Brown, V.K.; Butterfield, J.; Buse, A.; Coulson, J.C.; Farrar, J.; et al. Herbivory in global climate change research: Direct effects of rising temperature on insect herbivores. Glob. Chang. Biol. 2002, 8, 1-16. [CrossRef]

6. Gely, C.; Laurance, S.G.W.; Stork, N.E. How do herbivorous insects respond to drought stress in trees? Biol. Rev. 2019, 95, 434-448. [CrossRef] 
7. Anderegg, W.R.; Hicke, J.A.; Fisher, R.A.; Allen, C.D.; Aukema, J.; Bentz, B.; Hood, S.; Lichstein, J.W.; Macalady, A.K.; McDowell, N.; et al. Tree mortality from drought, insects, and their interactions in a changing climate. New Phytol. 2015, 208, 674-683. [CrossRef]

8. Wilson, R.J.; Gutierrez, D.; Gutierrez, J.; Martinez, D.; Agudo, R.; Monserrat, V.J. Changes to the elevational limits and extent of species ranges associated with climate change. Ecol. Lett. 2005, 8, 1138-1146. [CrossRef]

9. Hill, J.K.; Thomas, C.D.; Fox, R.; Telfer, M.G.; Willis, S.G.; Asher, J.; Huntley, B. Responses of butterflies to twentieth century climate warming: Implications for future ranges. Proc. Biol. Sci. 2002, 269, 2163-2171. [CrossRef]

10. Thomas, C.D.; Cameron, A.; Green, R.E.; Bakkenes, M.; Beaumont, L.J.; Collingham, Y.C.; Erasmus, B.F.; De Siqueira, M.F.; Grainger, A.; Hannah, L.; et al. Extinction risk from climate change. Nature 2004, 427, 145-148. [CrossRef]

11. Volney, W.J.A.; Fleming, R.A. Climate change and impacts of boreal forest insects. Agric. Ecosyst. Environ. 2000, 82, 283-294. [CrossRef]

12. Pöyry, J.; Leinonen, R.; Söderman, G.; Nieminen, M.; Heikkinen, R.K.; Carter, T.R. Climate-induced increase of moth multivoltinism in boreal regions. Glob. Ecol. Biogeogr. 2011, 20, 289-298. [CrossRef]

13. Lehmann, P.; Ammunét, T.; Barton, M.; Battisti, A.; Eigenbrode, S.D.; Jepsen, J.U.; Kalinkat, G.; Neuvonen, S.; Niemelä, P.; Terblanche, J.S.; et al. Complex responses of global insect pests to climate warming. Front. Ecol. Environ. 2020, 18, 141-150. [CrossRef]

14. Venäläinen, A.; Lehtonen, I.; Laapas, M.; Ruosteenoja, K.; Tikkanen, O.-P.; Viiri, H.; Ikonen, P.; Peltola, H. Climate change induces multiple risks to boreal forests and forestry in Finland: A literature review. Glob. Chang. Biol. 2020, 26, 4178-4196. [CrossRef]

15. Netherer, S.; Schopf, A. Potential effects of climate change on insect herbivores in European forests-General aspects and the pine processionary moth as specific example. For. Ecol. Manag. 2010, 259, 831-838. [CrossRef]

16. Ayres, M.P.; Lombardero, M.J. Assessing the consequences of global change for forest disturbance from herbivores and pathogens. Sci. Total Environ. 2000, 262, 263-286. [CrossRef]

17. Roy, B.A.; Güsewell, S.; Harte, J. Response of plant pathogens and herbivores to a warming experiment. Ecology 2004, 85, 2570-2581. [CrossRef]

18. Jepsen, J.U.; Hagen, S.B.; Ims, R.A.; Yoccoz, N.G. Climate change and outbreaks of the geometrids Operophthera brumata and Epirrita autumnata in subarctic birch forest: Evidence of a recent outbreak range expansion. J. Anim. Ecol. 2008, 77, 257-264. [CrossRef]

19. Hance, T.; van Baaren, J.; Vernon, P.; Boivin, G. Impact of extreme temperatures on parasitoids in a climate change perspective. Annu. Rev. Entomol. 2007, 52, 107-126. [CrossRef]

20. Furlong, M.J.; Zalucki, M.P. Climate change and biological control: The consequences of increasing temperatures on hostparasitoid interactions. Curr. Opin. Insect. Sci. 2017, 20, 39-44. [CrossRef]

21. Pureswaran, D.S.; Roques, A.; Battisti, A. Forest insects and climate change. Curr. For. Rep. 2018, 4, 35-50. [CrossRef]

22. Marini, L.; Økland, B.; Jönsson, A.M.; Bentz, B.; Carroll, A.; Forster, B.; Grégoire, J.C.; Hurling, R.; Nageleisen, L.M.; Netherer, S.; et al. Climate drivers of bark beetle outbreak dynamics in Norway spruce forests. Ecography 2017, 40, 1426-1435. [CrossRef]

23. FAO. Abiotic Disturbances and Their Influence on Forest Health; Moore, B., Allard, G., Eds.; Forest Health and Biosecurity Working Paper FBS/35E; FAO: Rome, Italy, 2011.

24. IPCC. Climate Change 2013: The Physical Science Basis. In Contribution of Working Group I to the Fifth Assessment Report of the Intergovernmental Panel on Climate Change; Stocker, T.F., Qin, D., Plattner, G.-K., Tignor, M., Allen, S.K., Boschung, J., Nauels, A., Xia, Y., Bex, V., Midgley, P.M., Eds.; Cambridge University Press: Cambridge, UK; New York, NY, USA, 2013 ; p. 1535.

25. Haynes, K.J.; Allstadt, A.J.; Klimetzek, D. Forest defoliator outbreaks under climate change: Effects on the frequency and severity of outbreaks of five pine insect pests. Glob. Chang. Biol. 2014, 20, 2004-2018. [CrossRef]

26. Klapwijk, M.J.; Björkman, C. Mixed forests to mitigate risk of insect outbreaks. Scand. J. For. Res. 2018, 33, 772-780. [CrossRef]

27. Buras, A.; Menzel, A. Projecting Tree Species Composition Changes of European Forests for 2061-2090 Under RCP 4.5 and RCP 8.5 Scenarios. Front. Plant Sci. 2019, 9, 1986. [CrossRef]

28. Forest Europe. State of Europes's Forests. 2015. Available online: https://foresteurope.org/state-europes-forests-2015-report (accessed on 16 June 2021).

29. Huberty, F.; Denno, R.F. Plant water stress and its consequences for herbivorous insects: A new synthesis. Ecology 2004, 85, 1383-1398. [CrossRef]

30. Jactel, H.; Petit, J.; Desprez-Loustau, M.-L.; Delzon, S.; Piou, D.; Battisti, A.; Koricheva, J. Drought effects on damage by forest insects and pathogens: A meta-analysis. Glob. Chang. Biol. 2012, 18, 267-276. [CrossRef]

31. Mcmillin, J.D.; Wagner, M.R. Season and intensity of water stress: Host-plant effects on larval survival and fecundity of Neodiprion gillettei (Hymenoptera: Diprionidae). Ecol. Entomol. 1995, 24, 1251-1257. [CrossRef]

32. Gutbrodt, B.; Mody, K.; Dorn, S. Drought changes plant chemistry and causes contrasting responses in lepidopteran herbivores. Oikos 2011, 120, 1732-1740. [CrossRef]

33. Visser, M.E.; Adriaensen, F.; van Balen, J.H.; Blondel, J.; Dhondt, A.A.; Van Dongen, S.; Thomson, D.L. Variable responses to large-scale climate change in European Parus populations. Proc. R. Soc. Lond. B 2003, 270, 367-372. 